\title{
ANALISIS KEHILANGAN PENERIMAAN NEGARA DI SEKTOR PAJAK SEBAGAI KONSEKUENSI DARI PENGUKUHAN BESARAN KENAIKAN PTKP (Studi Kasus Pada Dirjen Pajak Nusa Tenggara)
}

\author{
Isnawati \\ Bq. Anggun HL. \\ Zuhrotul Isnaini \\ Lalu Takdir Jumaidi
}

\begin{abstract}
ABSTRAK
Terkait dengan wacana Pemerintah yang akan melakukan penyesuaian lagi terhadap besaran Penghasilan Tidak Kena Pajak (PTKP), banyak pihak yang menilai bahwa kenaikan PTKP ini membuat target pertumbuhan penerimaan negara dari Pajak Penghasilan (PPh) 21 atau karyawan tahun ini tidak akan tercapai. Namun selama ini Pemerintah tetap melakukan penyesuaian terhadap besaran PTKP tersebut dengan beranggapan bahwa kehilanagan angka penerimaan tersebut hanya bersifat sementara. Selain itu Pemerintah optimis untuk mengejar angka tersebut dari pertumbuhan penerimaan PPN, PPn BM, PPh Final serta dengan melakukan ekstensifikasi pajak melalui menambahn jumlah WP OP maupun WP Badan. Namun kenyataannya angka ini belum dapat terkejar dari kenaikan penerimaan Negara lainnya sebagai dampak dari kenaikan PTKP yang dilakukan oleh Pemerintah. Sehingga penelitian ini dirasakan sangat urgent dalam rangka memberikan bukti empiris mengenai dampak dari kenaikan PTKP yang dilakukan Pemerintah selama ini. Jenis Penelitian ini adalah penelitian Deskriptif, dan merupakan studi kasus yang dilakukan di Mataram, tepatnya pada Kanwil DJP Nusa Tenggara yang beralamatkan di Jalan Sriwijaya No.182-B Mataram 83126. Hasil penelitian menolak hipotesis yang dibangun, karena hasil penelitian menunjukkan bahwa besaran PTKP yang baru tidak memberikan dampak terhadap rata-rata penerimaan negara dari sector pajak. Hasil penelitian ini tidak mendukung opini Pemerintah yang menyatakan bahwa dengan penyesuaian besaran PTKP ini akan mampu meningkatkan daya beli Masyarakat yang nantinya akan meningkatkan penerimaan negara dari sector yang lainnya seperti PPN. Akan tetapi opini Pemerintah tersebut dibantah juga oleh hasil penelitian yang dilakukan oleh Jonathan dan Husaini (2014) bahwa tidak terbukti kenaikan PTKP akan meningkatkan daya beli Masyarakat.
\end{abstract}

Kata Kunci: Pajak Penghasilan, PTKP, Waib Pajak 


\section{PENDAHULUAN}

\section{Latar Belakang}

Penerimaan negara merupakan pemasukan yang diperoleh negara untuk membiayai dan menjalankan setiap program-program pemerintahan, sedangkan Sumber-sumber penerimaan Negara berasal dari berbagai sektor, dimana semua hasil penerimaan tersebut akan digunakan untuk membiayai pembangunan dan meningkatkan kesejahtraan seluruh rakyat Indonesia. Sumber-sumber penerimaan Negara antara lain pajak, retribusi, pinjaman,keuntungan BUMN/BUMD, dll, dan penerimaan negara yang paling potensial adalah dari peneriman pajak. Dapat dikatakan berbagai upaya dilakukan oleh Pemerintah untuk meningkatan penerimaan Negara yang bersumber dari pajak tersebut. Salah satunya dengan melakukan penyesuaian Pajak Tidak kena Pajak (PTKP).

Selama ini Pemerintah Indonesia telah melakukan beberapa kali perubahan jumlah PTKP. Yang pertama di tahun 1990 melalui keputusan Menteri Keuangan Republik Indonesia nomor 1209/KMK.04/1989, Kedua di tahun 1994 melalui Keputusan Menteri Keuangan RI nomor 928/KMK.04/1993, ketiga di tahun 1999 melalui KeputusanMenteri Keuangan RI nomor 361/KMK.04/1998, keempat di tahun 2005 melalui keputusan Menteri Keuangan RI nomor 564/KMK.03/2004, yang kelima di tahun 2006 melalui peraturan Menteri RI nomor 137/KMK.03/2005, keenam melalui Undang Undang RI nomor 36 tahun 2008 tentang perubahan keempat atas Undang Undang nomor 7 tahun 1983 tentang pajak penghasilan, dan yang terbaru adalah Peraturan Menteri Keuangan nomor 122/PMK.010/2015. Bahkan wacana yang sedang hangat dibicarakan saat ini bahwa Pemerintah berencana akan melakukan penyesuaian lagi untuk PTKP menjadi Rp.54 pertahunnya.

Kenaikan PTKP selalu menjadi perdebatan sejak dulu. Namun demikian kenaikan PTKP ini tentu saja akan berdampak pada hilangnya penerimaan pajak itu sendiri, karena beberapa data membuktikan bahwa kenaikan PTKP ini bisa menekan penerimaan pajak seperti yang termuat pada Bisnis Indonesia tanggal 27 Februari tahun 2009 menyatakan bahwa peningkatan besaran Penghasilan Tidak Kena Pajak (PTKP) sebesar Rp.13,2 juta pertahun menjadi Rp. 15,84 juta pertahun menyebabkan pemerintah kehilangan penerimaan pajak negara sebesar Rp. 11,8 trilliun pada tahun 2009.

Terkait dengan wacana Pemerintah yang akan melakukan penyesuaian lagi terhadap besaran PTKP, banyak pihak yang menilai bahwa kenaikan PTKP ini membuat target pertumbuhan penerimaan negara dari Pajak Penghasilan (PPh) 21 atau karyawan tahun ini tidak akan tercapai. Selama ini juga beberapa daerah di Indonesia telah membuktikan bagaimana kenaikan PPTKP ini mempengaruhi penerimaan PPh di di daerahnya.. Basuki Rahmat yang merupakan Kepala Bidang Penyuluhan 
Pelayanan dan Humas (P2H) Kanwil DJP Jateng II memberikan pernyataan pada harian Jogja.com pada hari kamis tanggal 7 april 2016 bahwa dari 1,013 Juta Wajib Pajak (WP) orang pribadi (OP), lebih dari 900.000 orang merupakan WP OP karyawan. Oleh karena itu revisi PTKP dinilai akan sangat berpengaruh terhadap capaian PPh karena jumlah WP OP karyawan akan berkurang. Lebih lanjut dikatakan bahwa kenaikan PTKP tahun sebelumnya telah berhasil membuat pertumbuhan PPh 21 pada semester II tahun lalu menjadi negatif. Hal ini dikarenakan sekitar 40\% PPh diperoleh dari potongan gaji karyawan.

Meskipun beberapa sumber menyatakan bahwa kenaikan PTKP selama ini memberikan dampak yang cukup signifikan terhadap hilangnya angka penerimaan negara dari PPh Pasal 21, namun selama ini Pemerintah tetap melakukan penyesuaian terhadap besaran PTKP tersebut dengan beranggapan bahwa kehilanagan angka penerimaan tersebut hanya bersifat sementara. Selain itu Pemerintah optimis untuk mengejar angka tersebut dari pertumbuhan penerimaan PPN, PPn BM, PPh Final serta dengan melakukan ekstensifikasi pajak melalui menambahn jumlah WP OP maupun WP Badan. Namun muncul pertanyaan apakah langkah langkah tersebut akan mampu mengejar ketertinggalan angka tersebut. Berikut adalah potensi dampak dari kenaikan PTKP tahun ini yang dirangkum Kemenkeu:

Tabel 1.1. Potensi Dampak Kenaikan PTKP

\begin{tabular}{|l|l|l|l|}
\hline \multicolumn{3}{|l|}{ Dampak Positif } & Dampak Negatif \\
\hline Kenaikan PPN dan PPn BM & Rp. 3,7 T & Pengurangan PPh OP & Rp. 25,4 T \\
\hline Kenaikan PPh Badan & Rp. 2,6 T & $\begin{array}{l}\text { Pengurangan Bea } \\
\text { keluar }\end{array}$ & Rp.0.048T \\
\hline Kenaikan Bea masuk & Rp. 0,22 T & & \\
\hline Jumlah & Rp. 6, 52T & Jumlah & Rp. 25,8T \\
\hline Selisih & Rp. 18,9 T & \\
\hline
\end{tabular}

Sumber : eksbis.sinyobis.com.

Pada tabel 1.1. di atas jelas memperlihatkan bahwa kenaikan PTKP memberikan dampak yang cukup signifikan terhadap hilangnya beberapa penerimaan negara, khususnya yang bersumber dari PPh Pasal 21. Tabel 1 di atas memperlihatkan bagaimana kehilangan penerimaan negara ini belum dapat terkejar dari langkah strategis yang diambil oleh Pemerintah. Ada beberapa alasan pokok Pemerintah untuk dilakukan penyesuaian besaran PTKP di tahun 2015 ini. Pertama, untuk menjaga daya beli masyarakat. Sebagaimana diketahui dalam beberapa tahun terakhir terjadi pergerakan harga kebutuhan pokok yang cukup signifikan, khususnya pada tahun 2013 dan 2014 sebagai dampak dari kenaikan harga BBM. Dimana bagi orang pribadi penghasilan merupakan alat untuk meningkatkan kesejahteraan, namun kesehtareaan tersebut terbentur dengan adanya Pajak Penghasilan yang dapat mengurangi nilai penghasilan mereka. Kedua, dalam beberapa tahun terakhir ini terjadi penyesuaian Upah Minimum Propinsi (UMP) dan Upah Minimum Kabupaten/Kota (UMK) di hampir setiap 
daerah. Ketiga, terkait kondisi perekonomian terakhir yang menunjukkan tren perlambatan ekonomi yang salah satunya disebabkan oleh perlambatan ekonomi global mitra dagang utama Indonesia. oleh karena itu Pemerintah beranggapan bahwa kehilanagan angka penerimaan tersebut hanya bersifat sementara. Selain itu Pemerintah optimis untuk mengejar angka tersebut dari pertumbuhan penerimaan PPN, PPn BM, PPh Final serta dengan melakukan ekstensifikasi pajak melalui menambahn jumlah WP OP maupun WP Badan. Namun kenyataannya, berdasarkan tabel 1 di atas bahwa angka penerimaan negara yang hilang jauh melebihi angka penerimaan yang bertambah sebagai dampak dari peningkatan daya beli masyarakat.

\section{Perumusan Masalah Penelitian}

Berdasarkan uraian pada latar belakang tersebut, dapat disimpulkan bahwa belum ada model yang efektif untuk mengejar kehilangan angka penerimaan negara tersebut. oleh karena itu masalah dalam penelitian ini dapat dirumuskan sebagai berikut: "Apakah penyesuaian besaran PTKP memiliki dampak terhadap kehilangan penerimaan Negara di sector pajak?".

\section{Tujuan Penelitian}

Sebagaimana yang telah diuaraikan di atas bahwa penyesuaian kenaikan PTKP yang dilakukan oleh Pemerintah selama ini masih menyisakan masalah dari sisi hilangnya penerimaan negara yang cukup signifikan dari PPh Pasal 21 dan yang lainnya. Dan angka ini belum dapat terkejar dari kenaikan penerimaan negara lainnya sebagai dampak dari kenaikan PTKP yang dilakukan oleh Pemerintah. Sehingga diperlukan model baru sebagai solusi dalam mengatasi kehilangan penerimaan negara di sektor pajak sebagai konsekuensi dari pengukuhan besaran kenaikan ptkp oleh pemerintah. Untuk itu sebagai langkah awal, penelitian ini mencoba melihat dampak dari penyeseuaian PTKP tersebut terhadap hilangnya penerimaan Negara di sector pajak.

\section{Urgensi dan Manfaat Penelitian}

Wacana yang menyatakan keinginan Pemerintah untuk melakukan penyesuaian terhadap besaran PTKP tiap tahunnya tentu menjadi sebuah polemik di kalangan Dirjen Pajak. Karena kenaikan PTKP ini memberikan dampak yang cukup signifikan terhadap hilangnya penerimaan negara. Dengan demikian penelitian ini sangat urgen untuk melihat dampak dari penyesuaian PTKP tersebut terhadap hilangnya penerimaan Negara di sector pajak penghasilan, dengan demikian hasil penelitian ini diharapkan dapat memberikan rekomendasi bagi Pemerintah untuk mengukuhkan atau tidak mengenai wacana kenaikan PTKP setiap tahunnya. Selain itu, hasil penelitian ini diharapkan bermanfaat untuk dijadikan sebagai tambahan referensi bagi para akademisi. Dalam hal ini bagi dosen maupun bagi 
mahasiswa yang ingin memperluas penelitian di sector pajak, khususnya mengenai PTKP.

\section{TINJAUAN PUSTAKA}

\section{Tinjauan Teoritis}

\section{Penghasilan Tidak Kena Pajak (PTKP): Teori Gaya Pikul}

Teori Gaya Pikul menyatakan bahwa dasar keadilan pemungutan pajak terletak pada jasa jasa yang diberikan oleh negara kepada warganya, yaitu perlindungan atas jiwa dan harta bendanya. Untuk kepentingan tersebut, diperlukan biaya biaya yang harus dipikul oleh segenap orang yang menikmati perlindungan itu, yaitu dalam bentuk pajak. Teori ini menekankan pada asas keadilan, bahwasanya pajak harus sama berat untuk setiap orang. Pajak harus dibayar menurut gaya pikul seseorang. Gaya pikul seseorang dapat diukur berdasarkan besarnya penghasilan dengan memperhitungkan besarnya pengeluaran atau pembelanjaan seseorang. Dalam pajak penghasilan untuk Wajib Pajak Orang Pribadi (WP OP), gaya pikul untuk pengeluaran atau pembelanjaan dinyatakan dengan sejumlah penghasilan tertentu yang tidak dikenakan pajak (Resmi: 2016: 6).

Selama ini Pemerintah Indonesia sudah beberapa kali melakukan perubahan terhadap besaran nilai PTKP, sejak tahun 1990 hingga yang terbaru pada tahun 2015. Bahkan wacana yang muncul, Pemerintah akan melakukan penyesuaian terhadap besaran PTKP setiap tahunnya. Tentu regulasi memberikan dampak dari berbagai aspek, khususnya dari aspek penerimaan negara yang bersumber dari Pajak Penghasilan.

\section{Daya Beli Masyarakat}

Daya beli masyarakat menurut Pass dan Lowes dalam buku Wachowicez (2007:119) adalah jumlah barang-barang atau jasa yang dibeli dengan sejumlah uang dengan harga barang-barang atau jasa yang telah tertentu. Wachowicez sendiri menyatakan dalam bukunya sendiri bahwa daya beli masyarakat (2007:119) adalah kemampuan masyarakat sekitar dalam membelanjakan uangnya untuk memenuhi kebutuhan barang atau jasa yang diperlukan oleh masyarakat tersebut. Jadi dapat dikatakan bahwa daya beli masyarakat itu menunjukkan tingkat perekonomian masyarakat tersebut.

Selama ini yang menjadi salah satu alasan pokok Pemerintah untuk dilakukan penyesuaian besaran PTKP adalah untuk menjaga daya beli masyarakat. Akan tetapi beberapa hasil penelitian menyatakan bahwa peningkatan daya beli masyarakat setelah kenaikan PTKP tidak begitu signifikan. 


\section{Pengertian Dan Ruang Lingkup Perpajakan}

Pada dasarnya, dalam kehidupan sehari-hari sering mendengar istilah pajak, namunpengertian yang sesungguhnya masih belum jelas artinya. Dalam Undang Undang Nomor 28 tahun 2007 tentang perubahan ketiga UU Nomor 6 tahun 1983 yakni Ketentuan Umum dan Tata Cara Perpajakan dinyatakan bahwa pajak adalah kontribusi wajib kepada negara yang terutang oleh Orang Pribadi atau Badan yang bersifat memaksa berdasarkan Undang Undang dengan tidak mendapatkan imbalan langsung dan digunakan untuk keperluan negara bagi sebesar-besarnya kemakmuran rakyat. Dari pengertian tersebut dapat ditarik kesimpulan tentang ciri-ciri yang melekat pada pengertian pajak:

1. dipungut oleh negara (baik pemerintah pusat maupun daerah). Iuran tersebut berupa uang yang dipungut disebabkan suatu keadaan, kejadian, dan perbuatan yang memberikan manfaat tertentu bagi seseorang.

2. dipungut/dipotong berdasarkan dengan kekuatan Undang Undang serta aturan pelaksanaannya.

3. dalam pembayaran pajak tidak dapat ditunjukkan adanya kontra prestasi langsung dan dapat ditunjuk.

4. diperuntukkan bagi pengeluaran pembayaran pemerintah yang bermanfaat bagi kemakmuran rakyat.

\section{Fungsi Pajak}

Ada dua fungsi pajak yaitu:

1. Fungsi penerimaan (budgetair) yaitu pajak sebagai sumber dana bagi pemerintah untuk membiayai pengeluaran-pengeluarannya.

2. Fungsi pengatur (regulerend) yaitu pajak sebagai alat untuk mengatur atau melaksanakan kebijakan pemerintah dalam bidang sosial dan ekonomi.

\section{Syarat Pemungutan Pajak}

Agar pemungutan pajak tidak menimbulkan hanmbatan atau perlawanan, maka pemungutan pajak harus memenuhi syarat sebagai berikut:

1. Pemungutan pajak harus adil (Syarat Keadilan)

2. Sesuai dengan tujuan hukum, yakni mencapai keadilan, Undang Undang dan pelaksanaan pemungutan harus adil. Adil dalam perundang-undangan di antaranya mengenakan pajak secara umum dan merata, serta disesusikan dengan kemampuan masing-masing, sedang adil dalam pelaksanaan yakni dengan memberikan hak bagi wajib pajak untuk mengajukan keberatan, penundaan dalam pembayaran, dan mengajukan banding kepada Majelis Pertimbangan Pajak.

3. Pemungutan pajak harus berdasarkan Undang Undang ( Syarat Yuridis) 
4. Di Indonesia, pajak diatur dalam UUD 1945 pasal 23A yang menyatakan bahwa pajak dan pungutan lain yang bersifat memaksa untuk keperluan negara diatur dengan undang-undang. Hal ini memberikan jaminan hukum untuk menyatakan keadilan, baik bagi negara maupun warganya

5. Tidak mengganggu perekonomian (Syarat Ekonomis) Pemungutan tidak boleh mengganggu kelancaran kegiatan produksi maupun perdagangan sehingga tidak menimbulkan kelesuan perekonomian masyarakat

6. Pemungutan pajak harus efisien (Syarat Finansial)

7. Sesuai fungsi budgetair, biaya pemungutan pajak harus dapat ditekan sehingga lebih rendah dari hasil pemungutannya.

8. Sistem pemungutan pajak harus sederhana.

9. Sistem pemungutan yang sederhana akan memudahkan dan mendorong masyarakat dalam memenuhi kewajiban perpajakannya. Syarat ini telah dipenuhi oleh undang undang perpajakan yang baru.

\section{Hukum Pajak Material dan Hukum Pajak Formal}

Hukum Pajak mengatur hubungan antara pemerintah (fiskus) selaku pemungut pajak dengan rakyat sebagai wajib pajak. Hukum pajak dibedakan menjadi dua yakni:

1. Hukum pajak material yakni memuat norma-norma yang menerangkan tentang keadaan, perbuatan, peristiwa hukum yang dikenai pajak (objek pajak), siapa yang dikenakan pajak (subjek pajak), berapa besar pajak yang dikenakan (tarif pajak), segala sesuatu yang timbul dan hapusnya utang pajak, serta hubungan hukum antara pemerintah dan wajib pajak. Contoh Undang Undang Pajak Penghasilan

2. Hukum pajak formal yakni memuat tentang bentuk/cara untuk mewujudkan hukum material menjadi kenyataan (cara melaksanakan hukum pajak material). Hukum ini memuat:

a. Tata cara penyelenggaraan (presedur) penetapan suatu utang pajak,

b. Hak-hak fiskus untuk mengadakan pengawasan terhadap para wajib pajak mengenai keadaan, perbuatan, dan peristiwa yang menimbulkan utang pajak.

c. Kewajiban wajib pajak misalnya menyelenggarakan pembukuan/pencatatan dan hak-hak wajib pajak misalnya mengajukan keberatan/banding. Contoh: Ketentuan Umum dan tata cara Perpajakan.

\section{Perubahan Penghasilan Tidak Kena Pajak di Indonesia (PTKP)}

Seiring dengan perubahan ekonomi di Indonesia, besarnya batasan Penghasilan Tidak Kena Pajak (PTKP) selalu berubah-ubah mengikuti perkembangan zaman.PTKP atau Penghasilan Tidak Kena Pajak merupakan pengurang bagi penghasilan bruto untuk menghitung PPh terutang Wajib 
Pajak Orang Pribadi dalam negeri. PTKP hanya berlaku untuk wajib pajak orang pribadi, untuk wajib pajak badan seperti perseroan terbatas, CV, yayasan, lembaga, dan badan lain tidak dapat menggunakan PTKP.

Menururt Darwis (2012) perubahan PTKP ini merupakan strategi dari pemerintah untuk menekan tingkat inflasi yang terus merangkak naik dan untuk memberikan stimulus konsumsi domestik sehingga dapat meningkatkan pertumbuhan ekonomi. Adapun perkembangan perubahan Penghasilan Tidak Kena Pajak dari masa ke masa yaitu :

- Priode 1 Januari 1984 s/d 31 Desember 1993

Dasar Hukum : Undang-Undang No. 8 Tahun 1983, besarnya PTKP yaitu :

a. Untuk diri Wajib Pajak sebesar Rp. 960.000,-

b. Tambahan untuk Wajib Pajak Kawin sebesar Rp. 480.000,-

c. Tambahan untuk seorang isteri yang penghasilannya digabung dengan penghasilan suami sebesar Rp. 960.000,-

d. Tambahan untuk keluarga sedarah dan semenda dalam garis keturunan lurus paling banyak tiga orang sebesar Rp. 480.000,-

- Priode 1 Januari 1994 s/d 31 Desember 1994

Dasar Hukum : Keputusan Menteri Keuangan Nomor 928/KMK.04/1993, besarnya PTKP yaitu:

a. Untuk diri Wajib Pajak sebesar Rp. 1.728.000,-

b. Tambahan untuk WP Kawin sebesar Rp. 480.000,-

c. Tambahan untuk seorang isteri yang penghasilannya digabung dengan penghasilan suamisebesar Rp. 1.728.000,-

d. Tambahan untuk keluarga sedarah dan semenda dalam garis keturunan lurus paling banyak tiga orang sebesar Rp. 480.000,-

- Periode 1 Januari 1995 s/d 31 Desember 1998

Dasar Hukum : Undang-Undang No. 10 Tahun 1994, besarnya PTKP yaitu:

a. Untuk diri Wajib Pajak (WP) sebesar Rp. 1.728.000,-

b. Tambahan untuk WP Kawin sebesar Rp. 864.000,-

c. Tambahan untuk seorang isteri yang penghasilannya digabung dengan penghasilan suami sebesar Rp. 1.728.000,-

d. Tambahan untuk keluarga sedarah dan semenda dalam garis keturunan lurus paling banyak tiga orang sebesar Rp. 864.000,-

- Periode 1 Januari 1999 s/d 31 Desember 2000

Dasar Hukum : Keputusan Menteri Keuangan Nomor 361/KMK.04/1998, besarnya PTKP yaitu :

a. Untuk diri Wajib Pajak sebesar Rp. 2.880.000,-

b. Tambahan untuk Wajib Pajak Kawin sebesar Rp. 1.440.000,-

c. Tambahan untuk seorang isteri yang penghasilannya digabung dengan penghasilan suami sebesar Rp. 2.880.000,- 
d. Tambahan untuk keluarga sedarah dan semenda dalam garis keturunan lurus paling banyak tiga orang sebesar Rp. 1.440.000,-

- Periode 1 Januari 2001 s/d 31 Desember 2004

Dasar Hukum : Undang-Undang No. 17 Tahun 2000, besarnya PTKP yaitu:

a. Untuk diri Wajib Pajak sebesar Rp. 2.880.000,-

b. Tambahan untuk Wajib Pajak Kawin sebesar Rp. 1.440.000,-

c. Tambahan untuk seorang isteri yang penghasilannya digabung dengan penghasilan suami sebesar Rp. 2.880.000,-

d. Tambahan untuk keluarga sedarah dan semenda dalam garis keturunan lurus paling banyak tiga orang sebesar Rp. 1.440.000,-

- Periode 1 Januari 2005 s/d 31 Desember 2005

Dasar Hukum : Keputusan Menteri Keuangan Nomor 564/KMK.03/2004, besarnya PTKP yaitu:

a. Untuk diri Wajib Pajak sebesar Rp.12.000.000,-

b. Tambahan untuk Wajib Pajak Kawin sebesar Rp. 1.200.000,-

c. Tambahan untuk seorang isteri yang penghasilannya digabung dengan penghasilan suami sebesar Rp. 12.000.000,-

d. Tambahan untuk keluarga sedarah dan semenda dalam garis keturunan lurus paling banyak tiga orang sebesar Rp. 1.200.000,-

- Periode 1 Januari 2006 s/d 31 Desember 2008

Dasar Hukum : Peraturan Menteri Keuangan Nomor 137/PMK.03/2005, besarnya PTKP yaitu:

a. Untuk diri Wajib Pajak sebesar Rp. 13.200.000,-

b. Tambahan untuk Wajib Pajak Kawin sebesar Rp. 1.200.000,-

c. Tambahan untuk seorang isteri yang penghasilannya digabung dengan penghasilan suami sebesar Rp. 13.200.000,-

d. Tambahan untuk keluarga sedarah dan semenda dalam garis keturunan lurus paling banyak tiga orang sebesar Rp. 1.200.000,-

\section{- Periode 1 Januari 2009 s/d 31 Desember 2012}

Dasar Hukum : Undang-Undang No. 36 Tahun 2008, besarnya PTKP yaitu:

a. Untuk diri Wajib Pajak sebesar Rp. 15.840.000,-

b. Tambahan untuk Wajib Pajak Kawin sebesar Rp. 1.320.000,-

c. Tambahan untuk seorang isteri yang penghasilannya digabung dengan penghasilan suami sebesar Rp. 15.840.000,-

d. Tambahan untuk keluarga sedarah dan semenda dalam garis keturunan lurus paling banyak tiga orang sebesar Rp. 1.320.000,-

- Periode 1 Januari 2013 s/d 31 Desember 2014

Dasar Hukum : Peraturan Menteri Keuangan Nomor

62/PMK.011/2012, besarnya PTKP yaitu:

a. Untuk diri Wajib Pajak sebesar Rp. 24.300.000,-

b. Tambahan untuk Wajib Pajak Kawin sebesar Rp. 2.025.000,- 
c. Tambahan untuk seorang isteri yang penghasilannya digabung dengan penghasilan suami sebesar Rp. 24.300.000,-

d. Tambahan untuk keluarga sedarah dan semenda dalam garis keturunan lurus paling banyak tiga orang sebesar Rp. 2.025.000,-

Sejak 1 Januari 2015 Dasar Hukum : Peraturan Menteri Keuangan nomor 122/PMK.010/2015, besarnya PTKP yaitu:

a. Untuk diri Wajib Pajak sebesar Rp. 36.000.000,-

b. Tambahan untuk Wajib Pajak Kawin sebesar Rp. 3.000.000,-

c. Tambahan untuk seorang isteri yang penghasilannya digabung dengan penghasilan suami sebesar Rp. 36.000.000,-

d. Tambahan untuk keluarga sedarah dan semenda dalam garis keturunan lurus paling banyak tiga orang sebesar Rp. 3.000.000,-

Dari uraian diatas, dengan adanya perubahan kenaikan PTKP pemerintah berharap dapat meningkatkan daya beli masyarakat dan sebagai intensif agar pertumbuhan ekonomi nasional dapat didorong melalui peningkatan konsumsi masyarakat.

\section{Tinjauan Penelitian Terdahulu}

Beberapa penelitian telah banyak menggali tentang dampak dari kenaikan PTKP ini, seperti berikut di bawah ini:

1. Penelitian yang dilakukan oleh Salim dan Syafitri (2009). Penelitian ini dilakukan pada KPP Pratama Palembang Ilir Barat. Tujuan penelitian ini adalah untuk mengetahui dampak kenaikan PTKP terhadap penerimaan perpajakan pada KPP Pratama Palembang Ilir Barat. Metode Penelitian yang dipernakan adalah dengan pendekatan kualitatif, Jenis data sekunder, dengan teknik pengumpulan data wawancara dan dokumentasi, serta teknik analisis data dengan analisis studi kasus. Hasil yang dicapai menunjukan bahwa kenaikan PTKP mengakibatkan terjadinya penurunan dan penaikan penerimaan perpajakan, khususnya pada pajak penghasilan (PPh). Selain itu juga kenaikan batas PTKP mempengaruhi jumlah wajib pajak yang ada. Rekomendasi yang dapat diberikan sebagai koreksi atau langkah perbaikan adalah pemerintah harus dapat meningkatkan kepercayaan masyarakat terutama dalam perpajakan, agar kebijakan yang ditetapkan oleh pemerintah mendapat dukungan dari masyarakat.

2. Penelitian yang dilakukan oleh Ramli (2006). Fokus permasalah penelitian ini adalah ingin melihat berapa besar perubahan sumber penerimaan pajak akibat penyesuaian PTKP?, berapa besar "potesial loss penerimaan PPh 21 akibat penyesuaian PTKP?. Hasil penelitian ini menunjukkan bahwa persentase potensi wajib pajak akibat perubahan PTKP sebesar $68,56 \%$ dan tidak potensinya sebesar $31,50 \%$. Selain itu hasil penelitian ini juga menunjukkan bahwa besarnya potesial loss pendapatan yang diterima akibat perubahan PTKP sebesar 38,39\%. 
Perubahan pendapatan tidak kena pajak akibat perubahan PTKP sebesar $46,22 \%$. Berdasarkan hasil temuan dalam penelitian ini, maka peneliti memberikan beberapa saran. Salah satunya saran yang diberikan kepada Dirjen Pajak yaitu Tarif pajak yang dikenakan pada penghasilan kena pajak perlu ditinjau kembali sehubungan dengan perubahan PTKP yang dinamis setiap tahun. Berdasarkan beberapa hasil penelitian tersebut, maka dapat disimpulkan bahwa dampak kenaikan PTKP terhadap hilangnya penerimaan negara dari sector pajak penghasilan cukup signifikan.

3. Penelitian yang dilakukan oleh Jonathan dan Husaini (2014). Tujuan dari penelitian ini yaitu melihat pengaruh kenaikan PTKP terhadap daya beli masyarakat di wilayah Kabupaten Kediri khususnya Desa Sambiresik Kecamatan Gampengrejo. Peneliti ingin meneliti kebenaran mengenai menaikan PTKP ,maka daya beli masyarakat akan meningkat juga yang sesuai dikatakan oleh pemerintah. Jenis penelitian yang digunakan dalam penelitian ini adalah pendekatan kuantitatif. Teknik pengumpulan data yang digunakan penelitian Kuesioner. Penelitian ini memakai skala likert sebagai skor dari kuesioner. Analisis data yang dipakai adalah Analisa deskriptif. Hasil penelitian dapat diketahui bahwa apabila variabel bebas (PTKP) bernilai (0) maka variabel terikat (Daya Beli) bernilai 3,938. Nilai Koefisien Leverage untuk variabel $X$ adalah sebesar -180. Pada uji regresi terdapat nilai sig 0,140, maka H0 diterima. Saran dari penelitian agar pemerintah lebih cermat lagi apabila ingin menaikan jumlah PTKP guna meningkatkan daya beli. Pemerintah dapat meningkatkan daya beli masyarakat dengan menaikan PTKP tetapi juga mengontrol harga kebutuhan pokok. Hasil peneltian tersebut telah berhasil membuktikan bahwa apa yang dikatakan oleh Pemerintah mengenai kenaikan PTKP akan mampu meningkatkan daya beli masyarakat tidak selamanya benar.

\section{Rerangka Konseptual}

Penelitian ini bertujuan menjawab permasalah yang diajukan dalam penelitian ini. Permasalahan tersebut adalah potensi hilangnya penerimaan negara dari PPh Pasal 21 yang diakibatkan oleh adanya penyesuaian PTKP baru baru ini. Salah satu alasan Menteri Keuangan melakukan penyesuaian terhadap nilai PTKP tersebut salah satunya adalah untuk meningkatkan daya beli masyarakat yang tentunya nanti harapannya akan bisa mendongkrak perekonomian makro. Apapun tujuan dari penyesuaian PTKP tersebut tidak bisa mengelakkan pemerintah dari hilangnya penerimaan negara dari PPh Pasal 21 yang sangat besar. Menurut Pemerintah, hilangnya penerimaan ini akan dikejar dengan pertumbuhan PPN,PPn BM, meningkatkan jumlah WP yang terdaftar. Akan tetapi menurut beberapa fakta yang diuraikan pada latar belakang menunjukkan bagaimana pertumbuhan PPN, PPn BM ataupun yang lainnya belum mampu menutupi 
angka hilangnya penerimaan PPh Pasal 21 tersebut. belum lagi langkah pemerintah untuk meningkatkan Jumlah WP terdaftar masih belum maksimal dari potensi WP yang ada. Selain itu salah satu faktor yang menjadi penyebab tidak bisanya mengejar kehilangan penerimaan PPh Pasal 21 tersebut, dikarenakan tingkat kepatuhan WP yang masih tergolong sangat rendah. Untuk lebih jelasnya permasalahan penelitian ini diperlihatkan pada Fishbone Diagram (Gambar 21.1).

Berdasarkan fishbone diagram 2.1 tersebut dapat dijelaskan bahwa permasalahan potensi hilangnya penerimaan negara dari PPh Pasal 21 yang cukup besar ternyata belum mendapatkan solusi penanganan yang tepat untuk menutupi kehilangan tersebut. selama ini peningkatan daya beli masyarakat yang diharapkan akan meningkatkan penerimaan PPN ataupun PPn BM dan yang lainnya belum mampu mengejar angka penerimaan yang hilang. Berdasarkan uraian tersebut, maka dapat disimpulkan bahwa penyesuaian besaran PTKP memiliki dampak terhadap kenaikan maupun penurunan terhadap penerimaan Negara dari sector pajak penghasilan.

Gambar 2.1: Fishbone Diagram Penelitian

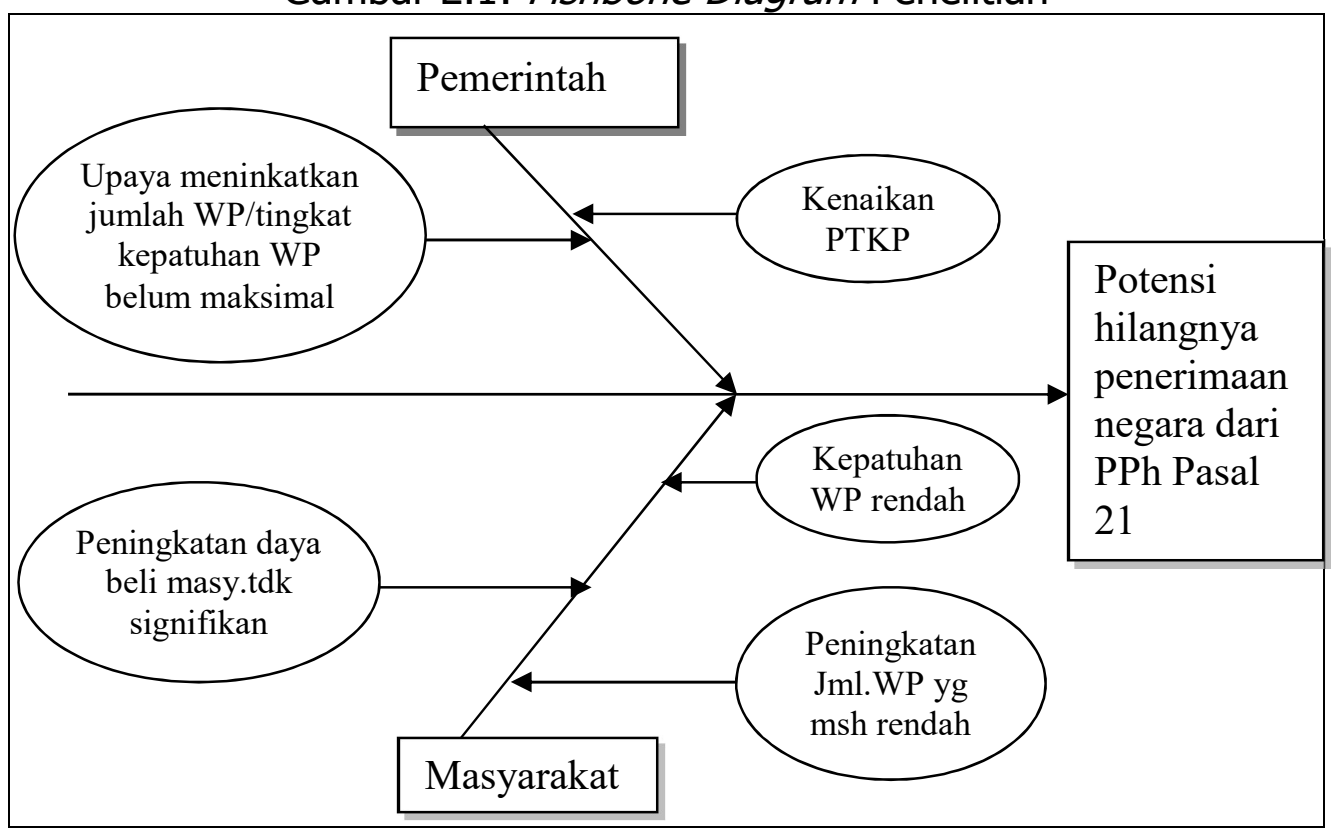

Beberapa penelitian terdahulu berhasil membuktikan bahwa kenaikan besaran PTKP mempengaruhi penerimaan Negara dari sector pajak. Hasil penelitian tersebut bervariasi, ada yang menemukan bukti bahwa kenaikan PTKP berdampak meningkatkan penerimaan negara dari sector pajak, namun ada juga yang menemukan bukti bahwa peyesuaian besaran PTKP malah menyebabkan peneurunan terhadap penerimaan negara dari sector pajak. Walaupun terdapat inkonsisten terhadap hasil penelitian terdahulu, akan tetapi dapat disimpulkan bahwa kenaikan besaran PTKP memiliki dampak terhadap penerimaan negara dari sector 
pajak, khususnya pajak penghasilan. Oleh karena itu dalam penelitian ini dapat ditarik sebuah jawaban sementara (hipotesis) seperti di bawah ini:

Ha : Penyesuaian besaran PTKP memberikan dampak terhadap penerimaan negara dari sektor pajak.

\section{METODE PENELITIAN}

\section{Jenis Penelitian}

Jenis penelitian ini adalah penelitian deskriptif. Menurut Sugiyono (2011), penelitian deskriptif adalah sebuah penelitian yang bertujuan untuk memberikan atau menjabarkan suatu keadaan atau fenomena yang terjadi saat ini dengan menggunakan prosedur ilmiah untuk menjawab masalah actual. Sedangkan menurut Sukmadinata (2006) menyatakan bahwa metode penelitian deksriptif adalah sebuah metode yang berusaha mendeskripsikan, menginterpretasikan sesuatu, misalnya kondisi atau hubungan yang ada, pendapat yang berkembang, proses yang sedang berlangsung akibat atau efek yang terjadi atau tentang kecendrungan yang sedang berlangsung.

\section{Prosedur Pengumpulan Data dan Sumber Data Prosedur Pengumpulan Data}

Pengumpulan data dilakukan dengan teknik studi kepustakaan atau biasa dikenal dengan istilah library research. Dengan demikian data penelitian tersebut adalah data yang berasal dari buku, dokumen, artikel dan lain lain. Maka dalam penelitian ini menggunakan laporan penerimaan pajak negara yang didokumentasikan oleh Dirjen Pajak Nusa Tenggara. Serta mengkaji artikel mengenai penyesuaian besaran PTKP dan dampaknya dibeberapa daerah di Indonesia, khususnya di wilayah Nusa Tenggara.

\section{Sumber Data}

Data penelitian ini adalah data sekunder. Data sekunder berupa data laporan penerimaan negara di sektor pajak, khususnya penerimaan PPh Pasal 21 di wilayah Dirjen Nusa Tenggara. Sumber data lainnya berupa studi kepustakaan, untuk mencari teori-teori yang berhubungan dengan topik penelitian.

\section{Lokasi Penelitian}

Penelitian ini dilakukan di Mataram, yaitu mengkaji data-data yang dikumpulkan pada Dirjen Nusa tenggara. Namun melihat permasalahan skala nasional yang terjadi di negara Indonesia. yaitu mengkaji dampak Peraturan Menteri Keuangan mengenai kenaikan PTKP terhadap hilangnya penerimaan negara dari PPh Pasal 21. 


\section{Jenis Data}

Pengumpulan data menggunakan teknik dokumentasi, yaitu data yang berasal dari cetak penting baik dari lembaga atau organisasi maupun dari perorangan. Jenis data yang dikumpulkan yaitu data kualitatif seperti peraturan pemerintah terkait dengan penyesuaian PTKP dan data kuantitaif seperti data data penerimaan negara dari PPh Pasal 21, PPN, PPn BM, PPh Final dll.

\section{Rancangan Penelitian}

Rancangan penelitian dapat dilihat pada Gambar 3.1.

\section{Definisi Operasional Variabel}

Variabel dalam penelitian ini adalah PPh, PPN, PPn BM. Adapun definisi secara singkat untuk variabel penelitian tersebut adalah:

- Pajak Penghasilan (PPh) Adalah pajak atas penghasilan berupa gaji, upah, honorarium, tunjangan, dan pembayaran lain yang diterima atau diperoleh Wajib Pajak orang pribadi dalam negeri sehubungan dengan pekerjaan atau jabatan, jasa, dan kegiatan.

- Pajak Pertambahan Nilai (PPN) adalah pajak yang dikenakan atas pertambahan nilai dari suatu barang maupun jasa yang dihasilkan.

- Pajak Penjualan atas Barang Mewah (PPnBM) adalah pajak yang dikenakan atas penjualan barang mewah.

\section{Definisi Operasional Variabel}

Variabel dalam penelitian ini adalah PPh, PPN, PPn BM. Adapun definisi secara singkat untuk variabel penelitian tersebut adalah:

- Pajak Penghasilan (PPh) Adalah pajak atas penghasilan berupa gaji, upah, honorarium, tunjangan, dan pembayaran lain yang diterima atau diperoleh Wajib Pajak orang pribadi dalam negeri sehubungan dengan pekerjaan atau jabatan, jasa, dan kegiatan.

- Pajak Pertambahan Nilai (PPN) adalah pajak yang dikenakan atas pertambahan nilai dari suatu barang maupun jasa yang dihasilkan.

- Pajak Penjualan atas Barang Mewah (PPnBM) adalah pajak yang dikenakan atas penjualan barang mewah.

\section{Analisis Data}

Jenis penelitian yang digunakan dalam penelitian ini adalah penelitian deskriptif. Metode yang digunakan untuk mendeskripsikan jawaban dari permasalahan yang dirumuskan dalam penelian ini menggunakan kajian pustaka. Pemilihan metode ini dikarenakan salah satu fungsi kajian pustaka adalah membantu memilih prosedur penyelesaian masalah penelitian. Serta melalui kajian pustaka ini juga akan bisa 
membantu peneliti untuk menemukan prosedur / model baru untuk solusi permasalahan penelitian (Hamdiyati : 2008: 1).

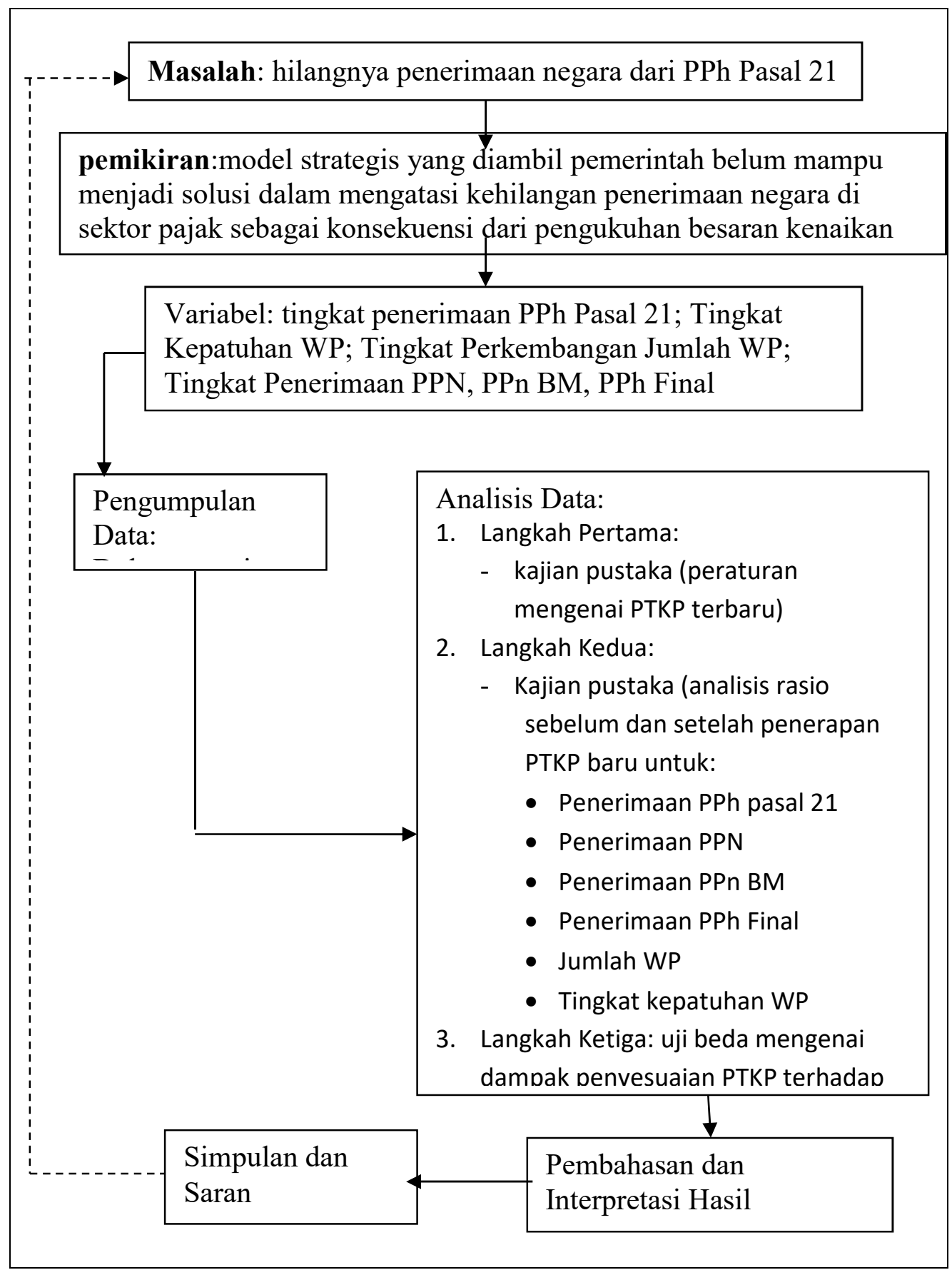

\section{Gambar 3.1: Rancangan Penelitian}

Kajian pustaka ini dilakukan dalam beberapa tahapan/langkah langkah sebagai berikut:

1. Mengumpulkan semua informasi dan data yang dibutuhkan melalui berbagai sumber, seperti sumber perpustakaan ataupun sumber 
publikasi di internet. Adapun informasi ataupun data data yang dibutuhkan untuk dikumpulkan adalah sebagai berikut:

- Informasi mengenai peraturan peraturan Pemerintah terkait dengan penyesuaian PTKP.

- Data APBN yang memperlihatkan penerimaan negara dari PPh Pasal 21, PPn, PPn BM, PPh Final, baik data sebelum maupun sesudah kenaikan PTKP.

- Data perkembangan Jumlah WP OP maupun WP Badan di Indonesia.

- Data tingkat Kepatuhan Wajib Pajak di Indonesia.

2. Melakukan analisis terhadap informasi/ data yang sudah dikumpulkan.

- Mengkaji sejarah penyesuaian PTKP di Indonesia.

- Menganalsis dampak dari kenaikan PTKP dilihat dari segi angka penerimaan negara, dengan cara melakukan uji beda terhadap penerimaan PPh Pasal 21, PPN. PPn BM, PPh Final.

Untuk menguji apakah terdapat perbedaan antara rata-rata tingkat kepatuhan WP Kabupaten Lombok Barat sebelum dan sesudah peristiwa penyitaan asset Hotel The Santosa dilakukan pengujian hipotesis. Uji hipotesis yang digunakan adalah uji beda rata-rata.

Pengujian hipotesis dalam penelitian ini sebagai berikut :

- $\mathrm{H}_{0}: \mu_{1}=\mu_{2}$, Rata-rata tingkat kepatuhan WP Kabupaten Lombok Barat sebelum dan sesudah tanggal penyitaan asset Hotel The Santosa tidak terdapat perbedaan secara signifikan.

- $\mathrm{H}_{\mathrm{a}}: \mu_{1} \neq \mu_{2}$, Rata-rata tingkat kepatuhan WP Kabupaten Lombok Barat sebelum dan sesudah tanggal penyitaan asset Hotel The Santosa terdapat perbedaan secara signifikan.

- Pengujian apakah nilai ini terletak dalam daerah penerimaan atau penolakan $\mathrm{H}_{0}$ dan untuk menguji hipotesis yang diajukan digunakan statistik uji t dengan rumus :

Dimana :

$$
\text { - } t=\frac{\bar{D}}{\left(\frac{S D}{\sqrt{N}}\right)}
$$

$$
\begin{array}{ll}
\mathrm{t} & =\text { Nilai thitung } \\
\bar{D} & =\text { Rata-rata selisih pengukuran } 1 \& 2 \\
\mathrm{SD} & =\text { Standar Deviasi selisih pengukuran } 1 \& 2 \\
\mathrm{~N} & =\text { Jumlah sampel }
\end{array}
$$

Kriteria pengujian penerimaan dan penolakan hipotesis adalah sebagai berikut :

Apabila thitung $>$ tabel maka $\mathrm{H}_{\mathrm{o}}$ ditolak

Apabila $t_{\text {hitung }}<\mathrm{t}_{\text {tabel }}$ maka $\mathrm{H}_{\mathrm{o}}$ diterima 
Tingkat signifikan yang dipilih adalah 0.05 karena nilai ini dapat mewakili pengaruh kedua variable dan merupakan tingkat signifikan yang umumnya digunakan dalam penelitian.

\section{HASIL DAN PEMBAHASAN}

\section{Gambaran Umum Objek Penelitian (Kanwil Dirjen Pajak Nusa Tenggara)}

Menurut Peraturan Meneteri Keuangan Republik Indonesia Nomor 70/PMK.03/2017 tentang Petunjuk Teknis Mengenai Akses Informasi keuangan untuk kepentingan Perpajakan menyatakan bahwa Kantor Wilayah Direktorat Jenderal Pajak yang selanjutnya disingkat Kanwil DJP adalah Instansi vertical Direktorat Jenderal Pajak yang berada di bawah dan bertanggung jawab langsung kepada Direktur Jenderal Pajak. DJP merupakan salah satu instansi pemerintah yang mempunyai peran penting dalam penerimaan Negara.

Organisais DJP memiliki jumlah kantor operasional lebih dari 500 unit kator dan jumlah pegawai lebih dari 39.000 orang yang tersebar di seluruh penjuru tanah air yang menjadikan DJP sebagai unit Eselon I terbesar di Kementrian Keuangan. Dan Kanwil Dirjen Pajak Nusa Tenggara merupakan Kantor Wilayah Direktorat Jenderal Pajak yang berada di wilayah penugasan Nusa Tenggara Barat dan Nusa Tenggara Timur. Kanwil Dirjen Pajak Nusa Tenggara berlokasi di Jalan Jenderal Sudirman Nomor 36 Rembiga Mataram, 83124.

Untuk mencapai visi dan melaksanakan misi tersebut di atas, ditetapkanlah tujuan, sasaran strategis, inisiatif strategis, dan program strategis. Dan dalam rangka mencapai tujuan serta memastikan terpenuhinya destination statement yang disusun, DJP menetapkan arah kebijakan Direktorat Jenderal Pajak tahun 2015-2019 sebagai berikut:

- Tahun 2015 : Pembinaan Wajib Pajak

- Tahun 2016 : Penegakan Hukum

- Tahun 2017 : Rekonsiliasi

- Tahun 2018 : Sinergi Instansi Pemerintah, Lembaga, Asosiasi dan Pihak Lain (ILAPI)

- Tahun 2019 : Kemandirian APBN

Berikut adalah Destination Statement Direktorat Jenderal Pajak Tahun 2015 - 2019:

Tabel 4.1. Destination Statement Direktorat jenderal Pajak tahun 20152019

\begin{tabular}{|l|l|l|l|l|l|}
\hline Indikator & 2015 & 2016 & 2017 & 2018 & 2019 \\
\hline Tax Ratio* & $13.2 \%$ & $14.2 \%$ & $14.6 \%$ & $15.2 \%$ & $16 \%$ \\
\hline $\begin{array}{l}\text { Penerimaan } \\
\text { Pajak }\end{array}$ & $1.294 \mathrm{~T}$ & $1.512 \mathrm{~T}$ & $1.737 \mathrm{~T}$ & $2.007 \mathrm{~T}$ & $2.329 \mathrm{~T}$ \\
\hline
\end{tabular}




\begin{tabular}{|l|l|l|l|l|l|}
\hline $\begin{array}{l}\text { SPT melalui } e- \\
\text { Filling }\end{array}$ & 2 Juta & 7 Juta & 14 Juta & 18 Juta & 24 Juta \\
\hline $\begin{array}{l}\text { Jumlah WP } \\
\text { terdaftar }\end{array}$ & 32 Juta & 36 Juta & 40 Juta & 42 Juta & 44 Juta \\
\hline$*$ temasuk 1\% pajak daerah \\
\hline
\end{tabular}

Sumber : Laporan Kinerja DJP 2016

Penelitian ini difokuskan pada DJP Wilayah Nusa Tenggara, khususnya Nusa Tenggara Barat (NTB) dengan alasan kemudaha dalam mengakses data penelitian.

\section{Deskripsi Data Penelitian}

Data penelitian ini adalah data sekunder. Data sekunder berupa data laporan penerimaan negara di sektor pajak, khususnya penerimaan PPh Pasal 21 di wilayah Dirjen Nusa Tenggara. Sumber data lainnya berupa studi kepustakaan, untuk mencari teori-teori yang berhubungan dengan topik penelitian. Pengumpulan data dilakukan dengan teknik studi kepustakaan atau biasa dikenal dengan istilah library research. Dengan demikian data penelitian tersebut adalah data yang berasal dari buku, dokumen, artikel dan lain lain. Maka dalam penelitian ini menggunakan laporan penerimaan pajak negara yang didokumentasikan oleh Dirjen Pajak Nusa Tenggara. Serta mengkaji artikel mengenai penyesuaian besaran PTKP dan dampaknya dibeberapa daerah di Indonesia, khususnya di wilayah Nusa Tenggara. Berikut adalah tabel Persentasi Realisasi Penerimaan pajak di Nusa Tenggara Barat sejak tahun 2013 hingga tahun 2016.

\begin{tabular}{|c|c|c|c|c|}
\hline \multicolumn{5}{|c|}{$\begin{array}{l}\text { Tabel 4.3. Persentasi realisasi Penerimaan Pajak } \\
\text { (dalam triliun rupiah) }\end{array}$} \\
\hline Tahun & 2013 & 2014 & 2015 & 2016 \\
\hline Target & 995.21 & $1,027.37$ & $1,294.26$ & $1,355.20$ \\
\hline Realisasi & 921.27 & 981.83 & $1,060.83$ & $1,105.81$ \\
\hline Capaian & $92.57 \%$ & $91.56 \%$ & $81.96 \%$ & $81.60 \%$ \\
\hline Tahun & & $\Delta 201$ & $4 \Delta 2014$ & $\Delta$ 2015-2016 \\
\hline Growth & & 6.92 & 7.68 & 4.24 \\
\hline
\end{tabular}

Sumber: Menu Kinerja Penerimaan Portal DJP

Berdasarkan tabel 4.3 di atas terlihat bagaimana realisasi penerimaan Pajak yang berfluktuasi wilayah Nusa Tenggara Barat. Dari tahun 2013 ke tahun 2014, realisasi penerimaan pajak meningkat sebanyak $6.92 \%$ dari 921.27 trilliun rupiah di tahun 2013 menjadi 981.83 trilliun rupiah di tahun 2014. Tahun 2015 meningkat sebesar 7.68\% dari tahun 2014 menjadi 1,060.83 trilliun rupiah. Dan di tahun 2016 juga mengalami 
peningkatan dari tahun 2015 sebesar 4.24\% menjadi 1,105.81 trilliun rupiah.

Akan tetapi jika dilihat dari indicator capaiannya dari target yang direncanakan, maka penerimaan pajaknya dari tahun ke tahun mengalami penururnan rata-rata minus $1 \%$ setiap tahunny. Tabel di atas merupakan data penerimaan pajak secara keseluruhan untuk wilayah Nusa Tenggara Barat. Berikut pada Tabel 4.4 merupakan data penerimaan pajak per jenis dari tahun 2013 sampai dengan 2016 untuk di wilayah Nusa Tenggara Barat.

Pada tabel 4.4 tersebut memperlihatkan gambaran target, penerimaan dan capaian pajak untuk setiap jenisnya di daerah Nusa tenggara Barat dari tahun 2013 hingga tahun 2016. Jika dilihat dari sisi penerimaan pajaknya, maka dapat disimpulkan rata-rata penerimaan setiap jenia pajak meningkat setiap tahunnya. Akan tetapi jika dilirik dari sisi capaian penerimaan pajaknya, yaitu perbandingan antara target dengan penerimaan pajaknya, maka data pada tabel tersebut menjelaskan adanya penururnan prosentase capaian setiap tahunnya. Terlebih pergerakan pada tahun 2014 ke 2015, tahun pertama mulai diberlakukannya besaran PTKP terbaru dari Rp.24.300.000 ke Rp.36.000.000. begitu juga pergerakan tahun 2015 ke tahun 2016 drastis menurun, mengingat pada tahun 2016 juga diberlakukan besaran PTKP baru dengan nilai Rp.54.000.000,-. Begitu juga dengan tabel 4.5 memperlihatkan penururnan capaian penerimaan pajak untuk setiap daerah di Nusa tenggara Barat, terlebih pergerakan data dari tahun 2014 ke 2015, dan dari 2015 ke 2016. 


\begin{tabular}{|c|c|c|c|c|c|c|c|c|c|c|c|c|c|c|c|c|c|c|c|}
\hline \multirow{14}{*}{ 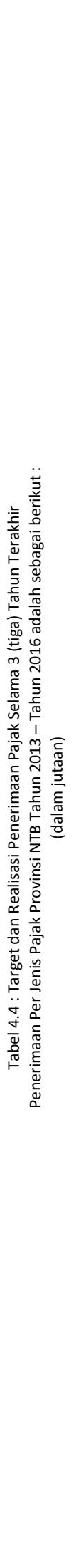 } & \multirow{3}{*}{$\stackrel{\text { : }}{\text { N }}$} & 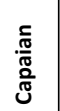 & 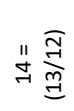 & $\begin{array}{c}\stackrel{\circ}{\circ} \\
\stackrel{m}{\sim} \\
\stackrel{m}{m}\end{array}$ & 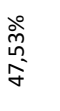 & 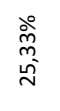 & 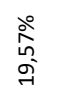 & 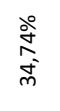 & 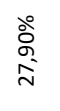 & $\begin{array}{l}\stackrel{\circ}{\circ} \\
\text { 总 } \\
\text { 心 }\end{array}$ & 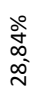 & $\stackrel{\stackrel{\mathrm{N}}{\mathrm{N}}}{\stackrel{\mathrm{N}}{\mathbf{n}}}$ & 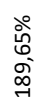 & $\begin{array}{l}\stackrel{\circ}{\circ} \\
\text { 令 }\end{array}$ & $\begin{array}{l}\text { 今े } \\
\text { : }\end{array}$ & $\begin{array}{l}\text { ㅇํㄹ } \\
\text { ì } \\
\text { ì }\end{array}$ & 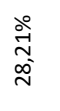 & 商 & 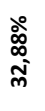 \\
\hline & & 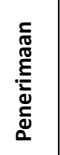 & $\stackrel{\eta}{q}$ & $\begin{array}{l}0 \\
\stackrel{0}{0} \\
\text { o. } \\
\infty\end{array}$ & 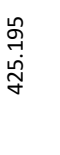 & $\begin{array}{l}\stackrel{d}{u} \\
\stackrel{\sim}{\sim}\end{array}$ & $\overrightarrow{\stackrel{\sigma o g}{\sigma}}$ & 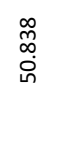 & 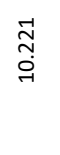 & 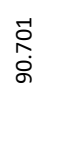 & 雚 & $\stackrel{\vec{\Phi}}{\sim}$ & $m$ & $\underset{\infty}{\stackrel{D}{\infty}}$ & $\mathscr{ర}_{0}^{\infty}$ & $\begin{array}{l}\tilde{\widetilde{J}} \\
\substack{\infty \\
\infty \\
\sim}\end{array}$ & 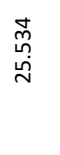 & $\stackrel{ \pm}{\mathbb{N}}$ & 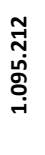 \\
\hline & & 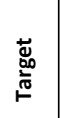 & $\approx$ & 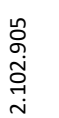 & 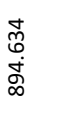 & 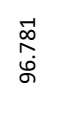 & $\underset{i}{\stackrel{\leftrightarrow}{i}}$ & $\begin{array}{l}\mathbb{J} \\
\stackrel{N}{0} \\
\stackrel{J}{J}\end{array}$ & 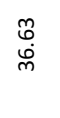 & 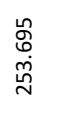 & 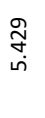 & $\begin{array}{l}\text { m } \\
\vec{t} \\
\dot{0} \\
0\end{array}$ & $\sim$ & $\underset{\overbrace{}}{\stackrel{\overbrace{}}{~}}$ & $\circ$ & 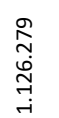 & 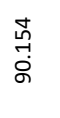 & $\begin{array}{l}\overrightarrow{\mid} \\
\stackrel{\leftrightarrow}{+} \\
\vec{H}\end{array}$ & 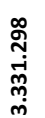 \\
\hline & \multirow{3}{*}{ : } & 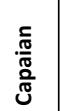 & " & 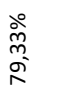 & 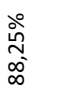 & $\begin{array}{l}\stackrel{\circ}{\hat{O}} \\
\hat{n} \\
\hat{\sigma}\end{array}$ & 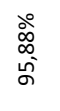 & $\begin{array}{l}\stackrel{\circ}{0} \\
\stackrel{0}{0}\end{array}$ & 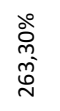 & $\begin{array}{l}\text { ڤે } \\
\hat{\alpha} \\
\hat{0}\end{array}$ & 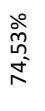 & $\begin{array}{l}\stackrel{0}{\circ} \\
\infty \\
\stackrel{i}{\wedge}\end{array}$ & $\begin{array}{l}\text { 今े } \\
\text { Oे } \\
\text { ì }\end{array}$ & $\begin{array}{l}\stackrel{\circ}{\hat{N}} \\
\stackrel{-}{-}\end{array}$ & $\begin{array}{l}\text { oे } \\
\text { o. }\end{array}$ & $\begin{array}{l}\text { ลे } \\
\hat{a} \\
\vec{\sigma}\end{array}$ & $\begin{array}{l}\text { 今े } \\
\text { ò } \\
\text { 今े }\end{array}$ & 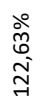 & 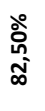 \\
\hline & & 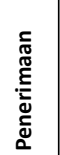 & $\stackrel{9}{9}$ & 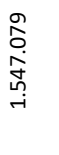 & 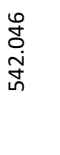 & 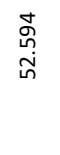 & $\stackrel{\infty}{\stackrel{\sim}{\sim}}$ & 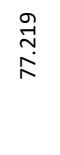 & 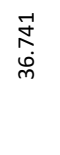 & $\begin{array}{l}\text { ָ̃ } \\
\stackrel{\sim}{+}\end{array}$ & & $\begin{array}{l}\stackrel{\omega}{\infty} \\
\stackrel{0}{0} \\
\infty \\
m\end{array}$ & $\stackrel{m}{\rightarrow}$ & $\sqrt{6}$ & $\underset{\widetilde{\sigma}}{\infty}$ & 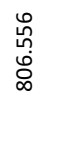 & 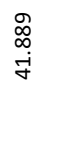 & 㤅 & \begin{tabular}{l} 
m \\
j. \\
\multirow{j}{*}{} \\
N
\end{tabular} \\
\hline & & 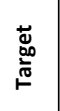 & $\sigma$ & 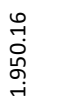 & 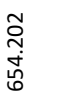 & 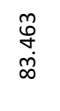 & $\stackrel{\text { 旾 }}{\rightarrow}$ & $\begin{array}{l}\vec{J} \\
\vec{J} \\
\stackrel{J}{7}\end{array}$ & 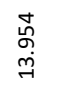 & 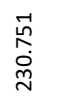 & i̊n & $\begin{array}{l}\stackrel{N}{N} \\
\stackrel{N}{n}\end{array}$ & $\sigma$ & $\hat{\mathrm{b}}$ & 0 & 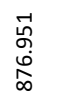 & $\underset{\infty}{\infty} \stackrel{\oplus}{\infty}_{\infty}^{\infty}$ & 岕 & 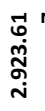 \\
\hline & \multirow{3}{*}{ : } & 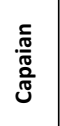 & 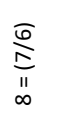 & 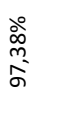 & $\begin{array}{l}\text { هें } \\
\text { ò } \\
\text { ă }\end{array}$ & 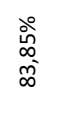 & 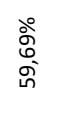 & 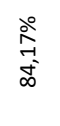 & 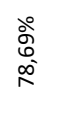 & 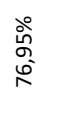 & 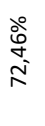 & 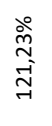 & 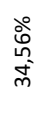 & 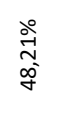 & 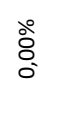 & 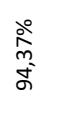 & $\begin{array}{l}\text { 今े } \\
\text { ळ. } \\
\text { ơ }\end{array}$ & $\begin{array}{l}\text { 今. } \\
\text { : } \\
\stackrel{0}{\circ}\end{array}$ & 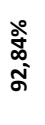 \\
\hline & & 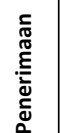 & r & 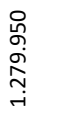 & 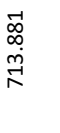 & 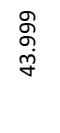 & 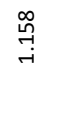 & $\begin{array}{l}\overrightarrow{\tilde{m}} \\
\stackrel{0}{\sigma}\end{array}$ & $\begin{array}{l}\stackrel{+}{+} \\
\stackrel{-}{-}\end{array}$ & $\begin{array}{l}\infty \\
\infty \\
o \\
\stackrel{్}{7}\end{array}$ & 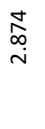 & 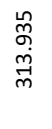 & $\sigma$ & $\stackrel{\sim}{ }$ & 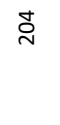 & $\begin{array}{l}\text { 今ี } \\
\text { ت्ञ }\end{array}$ & $\begin{array}{l}\vec{\infty} \\
\stackrel{\leftrightarrow}{\dot{\gamma}}\end{array}$ & 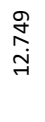 & 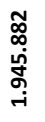 \\
\hline & & 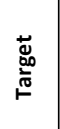 & 0 & 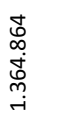 & 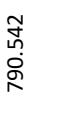 & 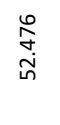 & $\underset{\rightarrow}{\vec{\sigma}}$ & $\begin{array}{l}\text { N } \\
\text { م. } \\
\text { g }\end{array}$ & $\stackrel{\stackrel{\sim}{\sim}}{\text { in }}$ & $\begin{array}{l}\text { ñ } \\
\text { 足 } \\
\text { 总 }\end{array}$ & 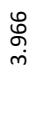 & 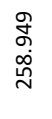 & $\vec{F}$ & $\tilde{F}$ & 0 & $\begin{array}{l}\hat{\tilde{n}} \\
\stackrel{0}{\hat{f}} \\
\hat{f}\end{array}$ & 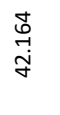 & 帝 & 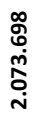 \\
\hline & \multirow{3}{*}{ : } & 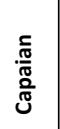 & $\begin{array}{l}\bar{m} \\
\frac{\hat{m}}{\|} \\
\underline{n}\end{array}$ & 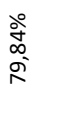 & 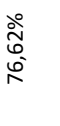 & $\begin{array}{l}\stackrel{\circ}{0} \\
\text { ஸे } \\
\infty \\
\infty\end{array}$ & 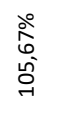 & 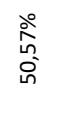 & $\begin{array}{l}\stackrel{\circ}{0} \\
\stackrel{0}{0}\end{array}$ & 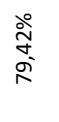 & 守 & $\begin{array}{l}\stackrel{\circ}{ } \\
\infty \\
\infty \\
\infty \\
\infty\end{array}$ & $\begin{array}{l}\text { ○ें } \\
\text { o. }\end{array}$ & 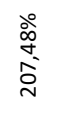 & $\begin{array}{l}\text { oे } \\
\text { o. }\end{array}$ & 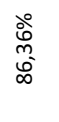 & 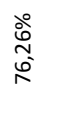 & 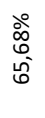 & \\
\hline & & 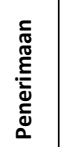 & $\sigma$ & 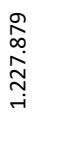 & 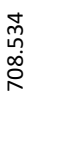 & $\begin{array}{l}\infty \\
\stackrel{\infty}{\circ} \\
\stackrel{0}{n} \\
\leftrightarrow\end{array}$ & $\underset{\rightarrow}{\tilde{T}}$ & $\begin{array}{l}\stackrel{\leftrightarrow}{\stackrel{0}{0}} \\
\stackrel{R}{R}\end{array}$ & $\begin{array}{l}\stackrel{f}{\infty} \\
\stackrel{\sim}{\sim} \\
\stackrel{\sim}{0}\end{array}$ & 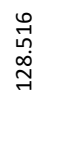 & $\stackrel{\substack{\infty \\
\stackrel{\infty}{\sim} \\
\sim}}{ }$ & $\stackrel{n}{\stackrel{n}{d}}$ & $\vec{F}$ & $\stackrel{m}{m}$ & $\stackrel{m}{\sim}$ & 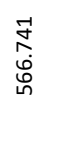 & 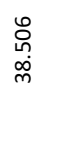 & 胥 & 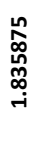 \\
\hline & & 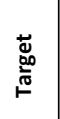 & $m$ & 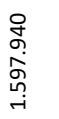 & 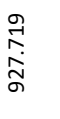 & 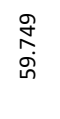 & $\underset{\underset{i}{I}}{\mathcal{I}}$ & 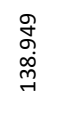 & 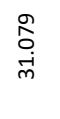 & $\begin{array}{l}\infty \\
\infty \\
\stackrel{\infty}{\oplus} \\
\stackrel{్}{1}\end{array}$ & ָু & 曽 & 0 & A & $\circ$ & $\begin{array}{l}\text { శ్ } \\
0 \\
0 \\
0 \\
0\end{array}$ & 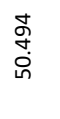 & 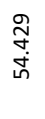 & 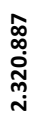 \\
\hline & $\hat{\underline{\hat{x}}}$ & & N & $\frac{c}{a}$ & 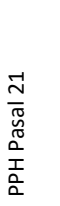 & 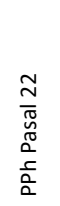 & 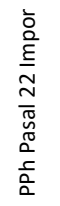 & $\begin{array}{l}\frac{n}{0} \\
\frac{0}{0} \\
\frac{0}{0} \\
\frac{a}{a} \\
\end{array}$ & 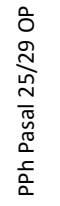 & 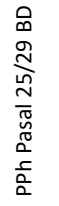 & 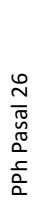 & 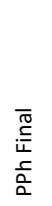 & 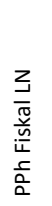 & 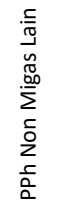 & 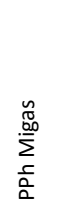 & 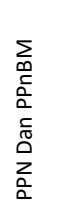 & 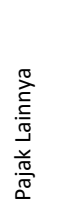 & ळొ & 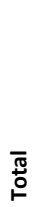 \\
\hline & z & & -1 & 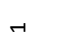 & & & & & & & & & & & & $\sim$ & $m$ & $\sigma$ & \\
\hline
\end{tabular}




\begin{tabular}{|c|c|c|c|c|c|c|c|c|c|}
\hline \multirow{14}{*}{ 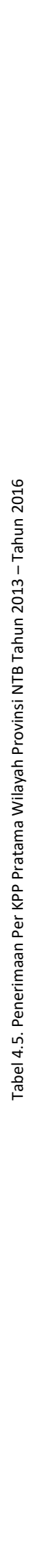 } & \multirow{3}{*}{ : } & 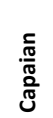 & 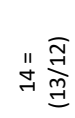 & $\begin{array}{l}\text { よ̊ } \\
\text { مे } \\
\text { - }\end{array}$ & 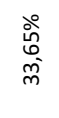 & 今े & $\begin{array}{l}\stackrel{\circ}{\text { సे }} \\
\text { N }\end{array}$ & $\begin{array}{l}\text { 今. } \\
\text { के } \\
\text { के }\end{array}$ & 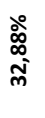 \\
\hline & & 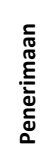 & 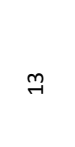 & $\begin{array}{l}\tilde{O} \\
\infty \\
\dot{y} \\
\forall\end{array}$ & 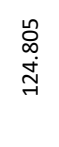 & 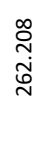 & 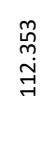 & 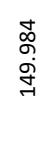 & 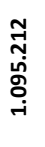 \\
\hline & & 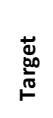 & $\approx$ & 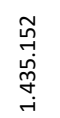 & 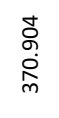 & 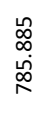 & $\begin{array}{l}\stackrel{0}{0} \\
\stackrel{\oplus}{9} \\
\stackrel{m}{m}\end{array}$ & 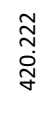 & 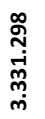 \\
\hline & \multirow{3}{*}{ 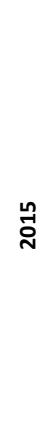 } & $\begin{array}{l}\frac{\mathrm{c}}{\mathrm{c}} \\
\frac{\mathrm{c}}{\mathrm{\sigma}} \\
\mathrm{d}\end{array}$ & " & 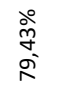 & $\begin{array}{l}\text { 今. } \\
\text { s. } \\
\text { s. }\end{array}$ & 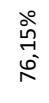 & $\begin{array}{l}\text { 今े } \\
\text { ने } \\
\text { స్ }\end{array}$ & 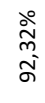 & 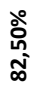 \\
\hline & & 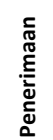 & $\stackrel{9}{9}$ & 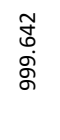 & $\begin{array}{l}\stackrel{J}{1} \\
\underset{\sim}{\tilde{N}}\end{array}$ & $\begin{array}{l}\text { o } \\
\text { ơ } \\
\text { o } \\
\text { h }\end{array}$ & $\begin{array}{l}\stackrel{\widetilde{m}}{2} \\
\stackrel{j}{\sim}\end{array}$ & 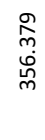 & 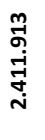 \\
\hline & & 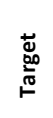 & $\sigma$ & $\begin{array}{l}\stackrel{0}{0} \\
0 \\
\stackrel{\infty}{0} \\
\stackrel{\sim}{n}\end{array}$ & 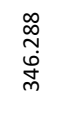 & $\begin{array}{l}\underset{\infty}{\mathbb{D}} \\
\underset{\sim}{\sim} \\
\text { J }\end{array}$ & 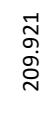 & 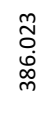 & 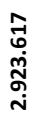 \\
\hline & \multirow{3}{*}{ ग्ञ } & $\begin{array}{l}\frac{\mathrm{c}}{\mathrm{c}} \\
\frac{\mathrm{c}}{\mathrm{\omega}} \\
\frac{\mathrm{d}}{\mathrm{J}}\end{array}$ & $\underset{\substack{\bar{D} \\
\infty}}{\underline{N}}$ & $\begin{array}{l}\text { すั } \\
\text { ڤ̆ }\end{array}$ & 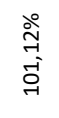 & $\begin{array}{l}\stackrel{\circ}{0} \\
\hat{a} \\
\stackrel{-}{-}\end{array}$ & $\begin{array}{l}\stackrel{\circ}{\circ} \\
\stackrel{\circ}{\circ} \\
\stackrel{\circ}{\circ}\end{array}$ & $\begin{array}{l}\text { ஓें } \\
\text { ले } \\
\text { बे }\end{array}$ & 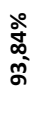 \\
\hline & & 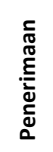 & r & 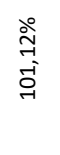 & 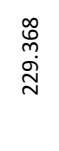 & 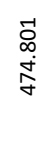 & 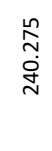 & $\begin{array}{l}\stackrel{8}{\square} \\
\stackrel{9}{q} \\
\text { gे }\end{array}$ & 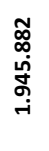 \\
\hline & & 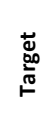 & 0 & $\begin{array}{l}\stackrel{\circ}{2} \\
\hat{a} \\
\text { - }\end{array}$ & 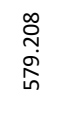 & \begin{tabular}{l} 
o \\
\multirow{n}{0}{} \\
\multirow{1}{n}{}
\end{tabular} & 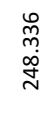 & 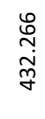 & 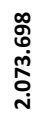 \\
\hline & \multirow{3}{*}{ 今. } & 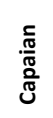 & $\underset{\substack{\bar{m} \\
\underline{n}}}{\underline{n}}$ & 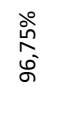 & $\begin{array}{l}\stackrel{0}{\circ} \\
\stackrel{0}{0}\end{array}$ & $\begin{array}{l}\text { 今े } \\
\stackrel{0}{\circ} \\
\stackrel{0}{8}\end{array}$ & 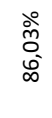 & $\begin{array}{l}\text { 今े } \\
\text { ठे. } \\
\text { ळे }\end{array}$ & $\begin{array}{l}\text { के̀ } \\
\text { sं } \\
\text { s. }\end{array}$ \\
\hline & & 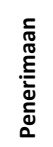 & $\sigma$ & $\begin{array}{l}\text { ஓे } \\
\text { ò } \\
\text { gे }\end{array}$ & 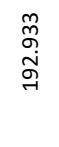 & $\begin{array}{l}\vec{\infty} \\
\stackrel{\vec{p}}{n}\end{array}$ & 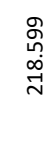 & 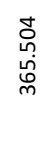 & 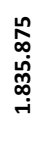 \\
\hline & & 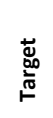 & $m$ & $\begin{array}{l}\text { No } \\
\stackrel{\tilde{N}}{\mathrm{\sigma}}\end{array}$ & $\begin{array}{l}\stackrel{0}{1} \\
\stackrel{\sim}{\tilde{n}}\end{array}$ & 莺 & $\begin{array}{l}\vec{s} \\
\vec{j} \\
\stackrel{d}{N}\end{array}$ & 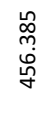 & 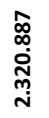 \\
\hline & $\frac{\hat{a}}{\underline{y}}$ & & $\sim$ & 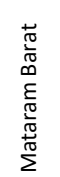 & 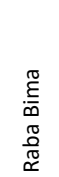 & 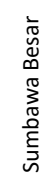 & 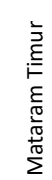 & 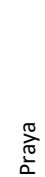 & 慇 \\
\hline & $\stackrel{\circ}{2}$ & & $r$ & $r$ & $\sim$ & $m$ & $\sigma$ & in & \\
\hline
\end{tabular}




\section{Analisa Statistik}

Penelitian ini bertujuan untuk mengetahui apakah terdapat pengaruh penyesuaian PTKP terhadap penerimaan pajak di DJP Nusa Tenggara khususnya di Nusa tenggara Barat. Untuk memenuhi tujuan penelitian tersebut dilakukan analisis deskriptif serta dilakukan analisis statistic dengan melakukan uji beda T-test paired samples untuk membuktikan adanya dampak penyesuaian PTKP terhadap penerimaan pajak di Nusa Tenggara Barat. Pengujian ini dilakukan dengan melihat adanya perbedaan rata-rata penerimaan pajak sebelum dan sesudah penerapan PTKP baru. Berikut adalah hasil uji beda yang dilakukan dengan bantuan program SPSS versi 16 diperlihatkan pada tabel 4.5; tabel 4.6 dan tabel 4.7.

Tabel 4.6. Paired Samples Statistics

\begin{tabular}{|c|c|c|c|c|}
\hline & Mean & $\mathrm{N}$ & $\begin{array}{c}\text { Std. } \\
\text { Deviation }\end{array}$ & $\begin{array}{c}\text { Std. Error } \\
\text { Mean }\end{array}$ \\
\hline Pair 1 Sebelum & 74.087 & 27 & 40.5516 & 7.8042 \\
\hline Sesudah & 74.794 & 27 & 78.4881 & 15.1050 \\
\hline
\end{tabular}

Tabel 4.6 di atas merupakan hasil dari Paired Samples Statistic. Tabel output tersebut dapat diketahui bahwa ada kenaikan penerimaan pajak di Nusa Tenggara Barat dari sebelum dan sesudah penerapan PTKP baru untuk tahun 2015 dan 2016. Adapun kenaikannya menunjukkan angka rata-rata 74.087 untuk periode sebelum penerapan PTKP baru, naik menjadi rata-rata 74.794 untuk periode sesudah penerapan PTKP baru.

Tabel 4.7. Paired Samples Correlations

\begin{tabular}{|l|r|r|r|}
\hline & $\mathrm{N}$ & $\begin{array}{c}\text { Correlatio } \\
\mathrm{n}\end{array}$ & Sig. \\
\hline Pair 1 $\begin{array}{l}\text { Sebelum \& } \\
\text { Sesudah }\end{array}$ & 27 & -.191 & .340 \\
\hline
\end{tabular}

Sumber: lampiran 1

Pada tabel 4.7 di atas menunjukkan output Paired Samples Correlation. Dari hasil tersebut dapat diketahui bahwa korelasi antara penerimaan pajak di Nusa tenggara Barat untuk sebelum dan sesudah penerapan PTKP baru sebesar -0.191. hal ini menjelaskan bahwa tidak terdapat hubungan yang signifikan untuk penerimaan pajak antara sebelum dan setelah penerapan PTKP baru pada tahun 20015 dan tahun 2016. 
Tabel 4.8. Paired Samples Test

\begin{tabular}{|c|c|c|c|c|c|c|c|c|}
\hline & \multicolumn{5}{|c|}{ Paired Differences } & \multirow[b]{3}{*}{$\mathrm{t}$} & \multirow[b]{3}{*}{ df } & \multirow{3}{*}{$\begin{array}{l}\text { Sig. (2- } \\
\text { tailed) }\end{array}$} \\
\hline & \multirow[b]{2}{*}{ Mean } & \multirow{2}{*}{$\begin{array}{c}\text { Std. } \\
\text { Deviation }\end{array}$} & \multirow{2}{*}{$\begin{array}{l}\text { Std. Error } \\
\text { Mean }\end{array}$} & \multicolumn{2}{|c|}{$\begin{array}{l}95 \% \text { Confidence } \\
\text { Interval of the } \\
\text { Difference }\end{array}$} & & & \\
\hline & & & & Lower & Upper & & & \\
\hline $\begin{array}{c}\text { Pair } 1 \text { Sebelum - } \\
\text { Sesudah }\end{array}$ & -.7074 & 94.9768 & 18.2783 & -38.2790 & 36.8642 & -.039 & 26 & .969 \\
\hline
\end{tabular}

Sumber : Lampiran 1

Tabel 4.8 di atas merupakan hasil (output) Paired Samples Test, dari tabel tersebut mneunjukkan bahwa kolom sig.(2-tailed) menunjukkan angka 0.969. hal ini berarti nilainya lebih besar dari 0.05 ( $a=5 \%$ ). Sehingga dapat kita simpulkan bahwa selisih penerimaan pajak di Nusa tenggara Barat sebelum dan sesudah pengenaan besaran PTKP baru untuk setiap jenis pajak sama dengan nol (0).

\section{Interpretasi hasil}

Tujuan penelitian ini sebagaimana yang diuraikan pada Bab I yaitu mencoba melihat dampak dari penyeseuaian PTKP tersebut terhadap hilangnya penerimaan Negara di sector pajak. Dan hal ini akan dijelaskan dengan menggunakan pengujian statistic yang dilakukan uji Beda (Paired Samples T-Test) dengan dengan bantuan program SPSS versi 16.

Berdasarkan pengujian statistic yang dilakukan pada tabel 4.6 sampai dengan tabel 4.8 di atas, khususnya tabel 4.7 dan 4.8. pada tabel 4.7 memperlihatkan kolom korelasi berada pada angka -0.191 , hal ini berarti tidak terdapat hubungan antara kenaikan PTKP dengan penerimaan pajak di Nusa Tenggara Barat baik sebelum maupun sesudah diberlakukannya kenaikan tersebut. Hal ini diperkuat dengan hasil test pada tabel 4.8, dimana kolom sig.(2-tailed) menunjukkan angka 0.969. Hal ini menyimpulkan bahwa selisih penerimaan pajak di Nusa Tenggara Barat baik sebelum maupun sesudah kenaikan PTKP baru pada tahun 2015 dan 2016 sama dengan nol (0). Artinya bahwa kenaikan PTKP tidak memiliki dampak terhadap penerimaan pajak di Nusa Tenggara Barat untuk setiap jenis pajaknya.

Hipotesis yang dibangun dalam penelitian ini adalah "Penyesuaian besaran PTKP memiliki dampak terhadap penerimaan negara dari sector pajak". Berdasarkan hasil penelitian yang dijelaskan di atas, khususnya pada pengujian statistic yang dilakukan yaitu uji beda untuk melihat adanya perbedaan selisih penerimaan negara dari sektor pajak baik sebelum aupun sesudah penyesuaian besaran PTKP. Adapun hasil uji beda menolak hipotesis yang dibangun, yaitu hasil penelitian menunjukkan bahwa besaran PTKP yang baru tidak memberikan dampak terhadap rata-rata penerimaan negara dari sector pajak. Akan tetapi jika dilihat lebih khusus lagi dampak ke tiap jenis pajak, maka data yang ada menunjukkan bahwa kenaikan 
PTKP mengakibatkan terjadinya penurunan dan kenaikan penerimaan perpajakan, khususnya pada pajak penghasilan (PPh). Hal ini sejalan dengan apa yang dihasilkan oleh Salim dan Syafitri (2009) yang menemukan bahwa kenaikan PTKP mengakibatkan terjadinya penurunan maupun kenaikan terhadap penerimaan perpajakan negara. Namun hasil penelitian ini tidak mendukung opini Pemerintah yang menyatakan bahwa dengan penyesuaian besaran PTKP ini akan mampu meningkatkan daya beli Masyarakat yang nantinya akan meningkatkan penerimaan negara dari sector yang lainnya seperti PPN. Akan tetapi opini Pemerintah tersebut dibantah oleh hasil penelitian yang dilakukan oleh Jonathan dan Husaini (2014) bahwa tidak terbukti kenaikan PTKP akan meningkatkan daya beli Masyarakat.

\section{KESIMPULAN DAN SARAN}

\section{Kesimpulan}

Perumusan masalah dalam penelitian ini yaitu " Apakah penyesuaian besaran PTKP memiliki dampak terhadap kehilangan penerimaan Negara di sector pajak?, dan Berdasarkan hasil penelitian yang dijelaskan di atas, khususnya pada pengujian statistic yang dilakukan yaitu uji beda untuk melihat adanya perbedaan selisih penerimaan negara dari sektor pajak baik sebelum aupun sesudah penyesuaian besaran PTKP. Adapun hasil uji beda menolak hipotesis yang dibangun, yaitu hasil penelitian menunjukkan bahwa besaran PTKP yang baru tidak memberikan dampak terhadap ratarata penerimaan negara dari sector pajak. Akan tetapi jika dilihat lebih khusus lagi dampak ke tiap jenis pajak, maka data yang ada menunjukkan bahwa kenaikan PTKP mengakibatkan terjadinya penurunan dan kenaikan penerimaan perpajakan, khususnya pada pajak penghasilan (PPh).

Hasil penelitian ini tidak mendukung opini Pemerintah yang menyatakan bahwa dengan penyesuaian besaran PTKP ini akan mampu meningkatkan daya beli Masyarakat yang nantinya akan meningkatkan penerimaan negara dari sector yang lainnya seperti PPN. Akan tetapi opini Pemerintah tersebut dibantah juga oleh hasil penelitian yang dilakukan oleh Jonathan dan Husaini (2014) bahwa tidak terbukti kenaikan PTKP akan meningkatkan daya beli Masyarakat.

\section{Keterbatasan penelitian}

Beberapa keterbatasan dalam penelitian ini diantaranya:

a. Penelitian ini melihat dampak kenaikan PTKP terhadap penerimaan perpajakan secara rata-rata, dimana dengan adanya kenaikan PTKP ini akan memberikan dampak menurunkan penerimaan negara dari sector pajak penghasilan (PPh), khususnya PPh Pasal 21 yang akan langsung mendapatkan dampaknya. Akan tetapi kenaikan PTKP ini juga akan meningkatkan penerimaan perpajakan yang lainnya. 
Tetunya jika dilihat dari sector perpajakan secara umum, hal ini kemungkinan memberikan andil dalam hasil penelitian ini yang belum mampu memperlihatkan dampak kenaikan PTKP terhadapa penerimaan perpajakan negara.

b. Penelitian ini terbatas dilakukan pada wilayah DJP Nusa Tenggara, khususnya Nusa Tenggara Barat. Lokasi penelitian juga dimungkinkan memberikan andil dalam hasil penelitian ini yang belum mampu membuktikan bahwa kenaikan PTKP tidak berdampak terhadap penerimaan perpajakan negara. Mengingat minimnya karyawan swasta yang akan lebih berdampak terhadap PPh Pasal 21nya. Wilayah Nusa Tenggara Barat juga minim akan sector industry yang akan menempatkan karyawan pada berbagai jenjang. Di sini lebih didominasi pada usaha kecil dan menengah,, yang artinya karyawan lebih didominasi pada level bawah, sehingga memungkinkan bahwa penghasilan mereka tidak memberikan sumbangsih yang berarti terhadap PPh Pasal 21. Karena penghasilan mereka di bawah PTKP.

\section{Saran}

Berdasarkan keterbatasan yang dijelaskan di atas, maka penelitian ini mengajukan beberapa saran yang bisa dilakukan oleh penelti selanjutnya yaitu:

a. Melakukan penelitian lebih spesifik melihat dampak kenaikan PTKP terhadap peerimaan perpajakan negara untuk setiiap jenisnya. Bukan menggunakan penerimaan perpajakan secara umum. Khususnya kehilangan penerimaan PPh Pasal 21 akibat kenaikan PTKP tersebut. Serta melihat secara khusus dapak kenaikan PTKP terhadap Perpajakan yang lainnya seperti PPN, PPnBM maupun yang lainnya.

b. Memilih lokasi penelitian yang merupakan sector industry, karena sector industry akan menempatkan karyawan leih banyak pada berbagai level. Mulai dari level bawah, menengah maupun level atas. Dengan kata lain memilih lokasi penelitian yang sekiranya mengalami dampak langsung dari kenaikan PTKP tersebut. 


\section{DAFTAR PUSTAKA}

Fitriandi, P; Yuda A; Agus P.P. 2015. Kompilasi Undang-Undang Perpajakan Terlengkap. Salemba Empat. Jakarta.pp.91.

UU RI Nomor 36 Tahun 2008 tentang Perubahan ke empat atas UU No 7 Tahun 1983 tentang Pajak Penghasilan

Per MenKeu Nomor 122/PMK.010/2015 tentang Penyesuaian besarnya Penghasilan Tidak Kena Pajak.

Bisnis Indonesia Tanggal 27 Februari Tahun 2009, diunggah pada hari 08 April 2016 Pukul 13.00 Wita.

www.ekbis.sinyobis.com

Resmi, Siti. 2016. Perpajakan Teori dan Kasus. Salemba Empat. Jakarta.pp. 6. Nutritomo. 2006. Pengaruh Peningkatan Penghasilan Tidak Kena Pajak terhadap Penerimaan Pajak Studi Pada KPP Yogyakarta Satu. Thesis. Universitas Atma Jaya Yogyakarta.pp. 1-24.

Jonathan, G; \& Husaini A.. 2014. Pengaruh Kenaikan Penghasilan Tidak Kena Pajak (PTKP) Terhadap Peningkatan Daya Beli Masyarakat di Daerah Kabupaten Kediri (Studi Kasus di Desa Sambireksik Kecamatan Gampengrejo). Jurnal e-Perpajakan No.1 Volume 1 Tahun 2014.pp.18.

Ramli. 2006. Analisis Perubahan PTKP Terhadap Penerimaan PPh 21 dan Ekonomi. Jurnal Wawasan, Februari 2006, Volume 11 Nomor 3.pp 134.

Farnika, N.E. 2010. Analisis Penerimaan Pajak Pada Kantor Wilayah Direktorat Jenderal Pajak Wajib Pajak Besar Setelah Pemberlakuan Kenaikan Penghasilan Tidak Kena Pajak. Thesis. Universitas Negeri Surabaya.pp.1-17.

Salim. M; \& Lili S. 2009. Analisis Pengaruh Kenaikan PTKP Terhadap Penerimaan Pajak Penghasilan Pada Kantor Pelayanan Pajak Pratama Palembang Ilir Barat. Thesis. STIE MDP. Pp. 1-8. Waluyo. 2011. Perpajakan Indonesia. Salemba Empat.Jakarta.

-------.2014. Perpajakan Indonesia. Salemba Empat. Jakarta.pp. 13.

Kep MenKeu RI Nomor 1209/KMK.04/1989 tentang besarnya faktor penyesuaian untuk menentukan penghasilan tidak kena pajak.

Kep MenKeu RI Nomor 928/KMK.04/1993 tentang besarnya faktor penyesuaian untuk menentukan penghasilan tidak kena pajak.

Kep Menkeu RI Nomor 361/KMK.04/1998 tentang besarnya faktor penyesuaian untuk menentukan penghasilan tidak kena pajak.

Kep MenKeu RI Nomor 564/KMK.03/2005 tentang besarnya faktor penyesuaian untuk menentukan penghasilan tidak kena pajak.

Harian Jogja.com, Kamis Tanggal 7 April 2016, diunggah pada hari Senin Tanggal 11 April 2016 Pukul. 14.00 Wita. 